\title{
Interactions between the Serotoninergic System and the Ionotropic GABA Receptors in Frog and Turtle Retina: An Immunofluorescent Study
}

\author{
Liliya Vitanova \\ Department of Physiology, Medical University of Sofia, Bulgaria \\ Email: lilyvita@abv.bg
}

\begin{abstract}
The aim of the present study was to elucidate the putative interactions between the serotoninergic and the GABAergic systems in the lower vertebrate retinas. Experiments were performed on 12-14 $\mathrm{m}$ frozen frog and turtle retinal sections, processed with more than 10 different antibodies directed against serotonin, GABA and their membrane receptors by means of the indirect immunocytochemical method. The results showed that some of the GABAergic retinal neurons possess the serotonin receptors 5-HT2A and 5-HT3A on their cell membrane, and vice versa: certain serotoninergic neurons possess the ionotropic $\mathrm{GABA}_{\mathrm{A}}$ and $\mathrm{GABA}_{\mathrm{C}}$ receptors. A simple neuronal chart is proposed to explain how the activation of serotonin receptors on a subgroup of GABAergic amacrine cells can decrease the $\mathrm{GABA}_{\mathrm{C}}$ receptor mediated inhibition on the retinal bipolar cells, the main generators of ERG. As the retina is a natural biological model of CNS, the relationships between both neurotransmitter systems described here may elucidate their participation in certain brain functions and to explain the possible mechanisms of action of some antidepressant drugs.
\end{abstract}

Keywords: Retina, neurotransmitters' interactions, serotonin, $\mathrm{GABA}_{\mathrm{A}}$ and $\mathrm{GABA}_{\mathrm{C}}$ receptors, 5HT2A and 5-HT3A receptors.

\section{Introduction}

Serotonin or 5-hydroxitryptamine is a monoamine, used in CNS both as neurotransmitter and neuromodulator. It is also represented in the retina, the last being known as part of the brain and its natural biological model. Retinal serotonin was localized mainly in the serotoninergic amacrine cells $[1,2$, 3]. Some authors localize serotonin in the retinal bipolar cells as well. The idea that serotonin in the bipolar cells is accumulated here from the retinal extracellular space was widely accepted until recently $[4,5,6]$. However, our last data [7] based on immunocytochemical experiments with an antibody against tryptophan hydroxylase - the key enzyme in the serotonin synthesis, showed unequivocally that some bipolar cells do synthesize serotonin. The same is true for some horizontal and single ganglion cells. It seems that serotonin retinal sources are more abundant than was previously believed which is in agreement with the results from recent genetic studies on the tryptophan hydroxylase mRNA expression in both distal and proximal retinal layers $[8,9]$. The actions of serotonin are mediated by numerous serotonin receptors subdivided into 7 large families - from 5-HT1 to 5-HT7 [for review see 10]. Representatives of all seven groups were proved to be widely distributed in the lower vertebrate retinas [7], which is an evidence for their active participation in the normal retinal functions.

Gamma-amino-butyric acid (GABA) is one of the main inhibitory neurotransmitters in CNS, as well as in the retina. The fast GABA effects are mediated by means of two subtypes of ionotropic GABA receptors: $\mathrm{GABA}_{\mathrm{A}}$ and $\mathrm{GABA}_{\mathrm{C}}$. Both subtypes are pentameric ion channels and mediate chloride currents. However, different subunits build up the $\mathrm{GABA}_{\mathrm{A}}$ and $\mathrm{GABA}_{\mathrm{C}}$ receptors' channels: while the GABA $_{A}$ channel is composed of alpha $(\alpha)$, betha $(\beta)$, gamma $(\gamma)$, delta $(\delta)$ etc. subunits (one of the most frequent combination is: $2 \alpha, 2 \beta$ and $1 \gamma)$, the GABA $_{C}$ channel is composed of rho $(\rho)$ subunits. It causes differences in the main characteristics of the chloride currents passing through them [for review see: 11]. In our first study on frog and turtle retinas we showed that $\mathrm{GABA}_{\mathrm{A}}$ and $\mathrm{GABA}_{\mathrm{C}}$ receptors were very well expressed in both retinal synaptic layers [12]. 
The aim of our study is to elucidate the putative interactions between these two retinal neurotransmitters systems. Based on the Ochoa-de la Paz et al.'s experiments, which showed that dopamine and serotonin may modulate negatively the GABA rho1 receptor expression in Xenopus laevis oocytes [13], we decided to study the interactions between serotonin - from one side, and the ionotropic GABA receptors - from other, in the retinas of the frog (Rana ridibunda) and the turtle (Pseudemys elegans). While the frog, a representative of class Amphybia, possesses mixed type of retina where both rod and cone photoreceptors are present, the turtle - belonging to class Reptilia, has predominantly cones in its retina. Both species belong to lower vertebrates whose retinas, due to the encephalization and corticalization of functions during the evolution, have more complex retinal organization in some aspects as compared to Mammals. That is why, frog and turtle retinas may represent a useful model for elucidation the possible interactions of both neurotransmitter systems in the Mammalian brain. The aim of the present study is to check out, using an immunofluorescence method, if the retinal serotoninergic neurons possess GABA receptors and vice versa: if the retinal GABAergic neurons possess on their cell membranes serotoninergic receptors. Thus we will be able to prove or to reject the idea that serotonin reduces the inhibitory effects of GABA mediated by its ionotropic receptors and to suggest a putative retinal network for this type of interactions between the two neurotransmitters systems.

\section{$2 \quad$ Materials and Methods}

All procedures with experimental animals were performed in accordance with the guidelines of Ethical commission of the Medical University of Sofia, Bulgaria and the EU legislation. The frog and the turtle were deeply anesthetized in water containing tricain-methanesulphonate $(1000 \mathrm{mg} / \mathrm{L})$, decapitated and pithed. The eyes were dissected and the posterior eyecups were immediately immersed in $4 \%$ paraformaldehyde in $0.1 \mathrm{M}$ phosphate buffer for 15-30 min. After fixation, the retinas were cryoprotected in graded sucrose solutions $(10 \%, 20 \%$ and 30\%). Further cryocut 12-14 $\mu$ m vertical retinal sections were obtained, which were stored at $-20^{\circ} \mathrm{C}$. Antibody labeling of the retinal sections was carried out using the indirect immuno-fluorescence method. Several different primary antibodies were used to identify immunocytochemically the serotoninergic and GABAergic neurons in the retina. These antibodies were directed against the neurotransmitters 5-hydroxitryptamine (5-HT, serotonin) and GABA. In addition, antibodies against tryptophan hydroxylase, a key enzyme in serotonin synthesis, and against the serotonin transporter were also used. The ionotropic GABA receptors were visualized by means of several anti-GABA ${ }_{\mathrm{A}}$ and anti-GABA $\mathrm{C}_{\mathrm{C}}$ primary antibodies, directed against different subunits of these receptors: alpha, gamma, rho1 and rho2. In addition: an antibody directed to the GABAA receptor associating protein (RAP), known to bind the gamma subunit of the receptor to the cytoskeleton, was also used.

From the serotoninergic receptors we selected to study the 5-HT3 and 5-HT2 receptors. The first one is the only ionotropic receptor from the large scope of serotoninergic receptors (its effect is depolarizing), while the second one is a metabotropic receptor, causing also a depolarizing effect.

Double labeling was performed using two antibodies: one directed against serotoninergic or GABAergic neurons, and the second - against the $\mathrm{GABA}_{\mathrm{A}}$ or $\mathrm{GABA}_{\mathrm{C}}$ receptor subunits or against the serotoninergic receptors 5-HT2 or 5-HT3 correspondingly. In such a way, combining two antibodies: one directed against certain neurotransmitter, and the second - against the receptors of the opposite neurotransmitter system, we aimed to confirm or reject a co-localization of the elements of the two neurotransmitters system in one and the same neuronal structure, which might elucidate their putative functional interaction.

The following primary antibodies are used:

1. A monoclonal rat anti-serotonin antibody (MAB352, Merck-Millipore). MAB352 reacts with serotonin in neurons and recognizes serotoninergic sites in fixed tissue sections. Dilution: 1:100 - 1:200.

2. A polyclonal rabbit anti-serotonin transporter antibody (5-hydroxitriptamine; 5-HT Transporter (Merck-Millipore) - recognizes the serotonin transporter protein. Dilution 1:200.

3. A polyclonal rabbit anti-tryptophan hydroxylase TPH (H-60) antibody (Santa-Cruz Biotechnology) recognizes aminoacids 385- 437 at the C-terminus of the enzyme tryptophan hydroxylase of human origin. It is also recommended for detection of TPH in other species. Dilution 1:100. 
4. A polyclonal goat anti-tryptophan hydroxylase antibody (Santa-Cruz Biotechnology) - raised against the internal region of the enzyme tryptophan hydroxylase. Dilution 1:100.

5. A monoclonal mouse anti SR-2A (A-4) antibody (Santa-Cruz Biotechnology) - raised against aminoacids 1-75 mapping within the N-terminal extracellular domain of the serotonin receptor SR-2A of human origin. Dilution 1:100.

6. A polyclonal rabbit anti SR-3A (H-138) antibody (Santa-Cruz Biotechnology) - raised against aminoacids 341- 478 at the C-terminus of the serotonin receptor SR-3A of human origin. Dilution $1: 100$.

7. A monoclonal mouse anti-GABA MAB 316 antibody ((Merck-Millipore) - specific for GABA; does not cross react with other amino acid at concentration 1:200 - 1:400.

8. A monoclonal mouse anti-GABA $\mathrm{R}$ alpha 1-6 antibody (Santa-Cruz Biotechnology). Dilution 1:100.

9. A polyclonal rabbit anti-GABA (A) gamma-1 antibody (Alomone labs) - peptide (C)HAGSTLIPMNNISMPQGE, corresponding to amino-acid residues 382-399 of rat GABA(A) gamma-1 receptor. Intracellular, C-terminus. Dilution 1:100 after reconstitution.

10. A monoclonal mouse anti-GABARAP (E-8) antibody (Santa-Cruz Biotechnology) - directed against the $\mathrm{GABA}_{\mathrm{A}}$ receptor associated protein, linking the $\mathrm{GABA}_{\mathrm{A}}$ receptor to the cytoskeleton. Dilution for immunofluorescence: 1:50 - 1:500.

11. A polyclonal rabbit anti-GABA(A) p1 receptor antibody (Alomon labs) - peptide (C)ESTVHWPGREVHE, corresponding to amino-acids residues 23-35 of rat GABA(A) p1 receptor. Extracellular, N-terminus. 1:200.

12. A polyclonal rabbit anti-GABA(A) $\mathrm{\rho} 2$ receptor antibody (Alomon labs) - peptide (C)RKRWTGHLETSKPSH, corresponding to amino-acids residues 51-65 of rat GABA(A) p2 receptor. Extracellular, N-terminus. Dilution: 1:200.

After incubation of the retinal sections with the primary antibodies for $16-18 \mathrm{~h}$, the secondary antibodies Alexa-Fluor with fluorescence in the green (488) or red region (594) of the spectrum were applied. Incubation with the secondary antibodies for an hour in dark was needed in order to visualize the primary antibodies localizations.

The sections were examined and photographed, using a Zeiss photomicroscope (Oberkochen, Germany), supplied by a digital camera. A part of the double labeling experiments were examined using confocal microscopy. All images are processed using Adobe Photoshop.

\section{$3 \quad$ Results}

To begin with, we present data showing the distribution of serotoninergic and GABAergic neurons, as well as of serotoninergic 5-HT2A and 5-HT3 receptors and ionotropic $\mathrm{GABA}_{\mathrm{A}}$ or $\mathrm{GABA}_{\mathrm{C}}$ receptors in the frog and turtle retinas. In addition, we present two series of double labeling with two antibodies one directed against the neurotransmitter (serotonin or GABA) and the other - against one of the receptor types belonging to the opposite neurotransmitter system. The latter experiments afford the opportunity to show the presence of serotonin receptors on the membrane of GABAergic neurons and vice versa. Similar co-localization might be interpreted as a ground for functional interaction between the two neurotransmitter systems.

\subsection{Serotoninergic System}

The distribution of serotoninergic neurons in the frog and turtle retina was described in details in our previous paper [7]. Three different antibodies, directed against: (1) the neurotransmitter serotonin, (2) the serotonin transporter embedded in the cell membranes of the serotoninergic neurons and (3) the enzyme tryptophane hydroxylase, a key enzyme in the serotonin synthesis, were used. All three antibodies produced well expressed staining in the frog and turtle retinas. In double labeling experiments, numerous co-localizations have been demonstrated between the above mentioned antibodies (not shown here). Our experiments unequivocally showed that the serotoninergic immunoreactivity was very well expressed in both frog and turtle retinas. Numerous cell bodies located in almost all nuclear layers, as well as well manifested synaptic staining in both plexiform layers were evident in the sections stained with anti-serotonin related antibodies (Fig. 1). The serotoninergic amacrine cells (ACs) were the most 
abundant amongst the different cell types. In addition to serotoninergic ACs, which were long been known as serotonin-synthesizing neurons [1, 2, 14), we succeeded to prove that additional retinal cell types possessed the capacity for serotonin synthesis as well, i.e. expression of the key enzyme for serotonin synthesis tryptophan hydroxylase. Firstly, this is a subgroup of bipolar cells (BC) which are immunopositive for both serotonin (Fig. 1) and tryptophan hydroxylase. They are not as numerous as the serotonin-synthesizing ACs. In our previous study [7] we demonstrated that the serotoninsynthesizing BCs are mainly located in the central parts of the retina, near the visual streak. The typical oblique course of their axons through the inner nuclear layer (INL) and the interconnections of their cell bodies with the Landoldt clubs in the outer nuclear layer (OPL) in the turtle retina prove that they are serotonin-synthesizing BCs [7].

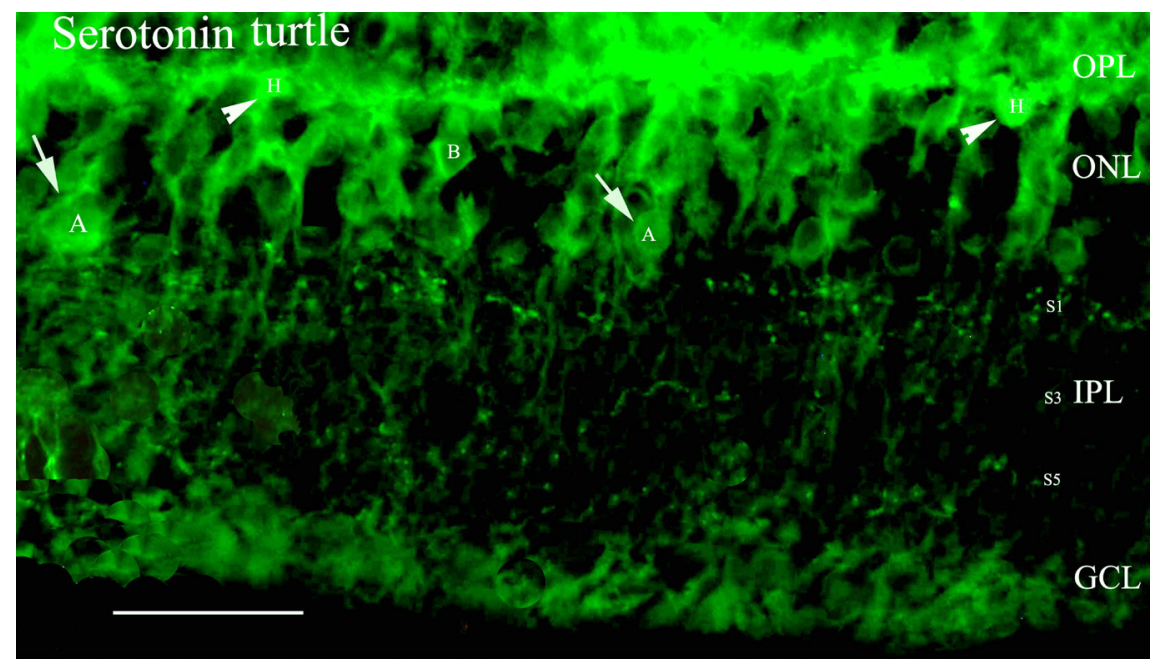

Figure 1. Photomicrograph of a vertical turtle retinal section, immunolabeled for serotonin. The retinal layers are as follows: ONL- outer nuclear layer; OPL - outer plexiform layer; INL - inner nuclear layer; IPL - inner plexiform layer; GCL - ganglion cell layer. Other notifications: H - horizontal cell; B- bipolar cell; A - amacrine cell; $\mathrm{S}_{1} ; \mathrm{S}_{3}$ and $\mathrm{S}_{5}$ - sublayers of the IPL. Scale bar: $40 \mu \mathrm{m}$.

In addition to ACs and BCs, single horizontal (HC) and even some ganglion cells (GC) were shown to be tryptophan hydroxylase-immunopositive. These data support the idea that the 5-HT synthesis is more widely distributed in lower vertebrate retinas than previously supposed. We believe that the serotonin retinal source is not single, which is in agreement with the recent genetic studies on the tryptophan hydroxylase mRNA expression in the retina $[8,9]$.

In our previous study on the serotoninergic neurotransmission [7] we also showed that a large number of representatives of all the seven groups of serotonin receptors are widely distributed in the frog and turtle retina. Currently, in order to elucidate the putative interactions between the serotoninergic and GABAergic system, we will focus on two serotonin receptors only: the 5-HT 2A and 5-HT 3A. While the 5 -HT2A is one of the numerous metabotropic serotonin receptors, the 5 -HT $3 \mathrm{~A}$ receptor is the only ionotropic receptor in the group. However, both receptors, when activated, produce depolarization of the postsynaptic structure. It is well known that even slight depolarization of the postsynaptic neuron increases the probability for neurotransmitter release by this neuron. That is why we decided, using double labeling experiments, to study in more details the 5-HT 2A and 5-HT 3A receptor distribution, hoping to find their putative "partners" amongst the GABAergic neurons.

The monoclonal mouse antibody against the 5-HT $2 \mathrm{~A}$ receptor caused well expressed staining in both frog and turtle retinas. In frog retina (Fig. 2), the outer and inner plexiform layers were brightly stained which means that 5-HT 2A is widely utilized in synaptic transmission both in the distal and proximal retina. Single horizontal and amacrine cell perikarya were also visualized. Some of the visualized ACs somata were almost embedded in the upper part of the IPL. Their main processes can be followed in some cases. Usually, they run horizontally in the $\mathrm{S}_{1}$ sublayer going in two opposite directions. In some sections one of these two processes can be followed to send collateral that goes down to the sublayer $\mathrm{S}_{3}$ of the IPL (see also Fig. 9). Similar effects of the antibody were observed in turtle retina as well. 


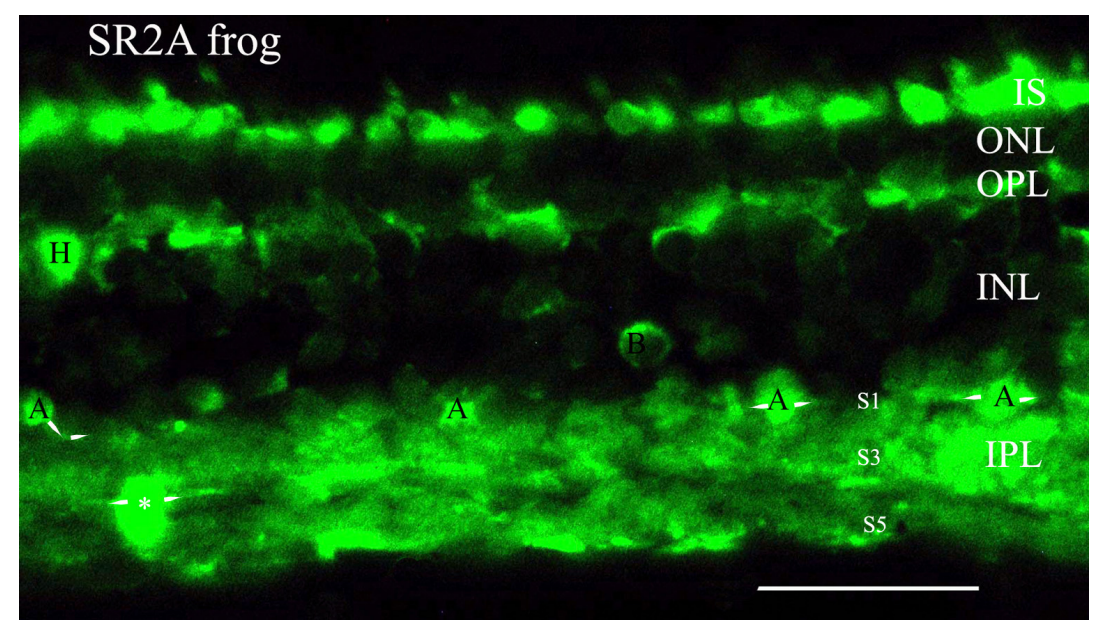

Figure 2. Photomicrograph of a vertical frog retinal section, immunolabeled for the serotonin receptor 5-HT 2A. Retinal layers are as follows: IS - inner segments of photoreceptors; ONL- outer nuclear layer; OPL - outer plexiform layer; INL - inner nuclear layer; IPL - inner plexiform layer; GCL - ganglion cell layer. Other notifications: $\mathrm{S}_{1} ; \mathrm{S}_{3}$ and $\mathrm{S}_{5}$ - sublayers of the IPL; $\mathrm{H}$ - horizontal cell; B- bipolar cell; A - amacrine cell. Please, pay attention to the two round shaped amacrine cells, each of them possessing two processes located at $180^{\circ}$ angle to each other, which leave the soma and spread in two opposite directions (indicated by the small white arrowhead) in the $S_{1}$ sublayer of the IPL. A putative amacrine cell with the same shape, embedded in the IPL, is indicated by means of a small white asterisk. A pear shaped AC with cell body located above the IPL and single process leaving its body is also 5-HT2A immunopositive (left part of the photomicrograph). Scale bar: $50 \mu \mathrm{m}$.

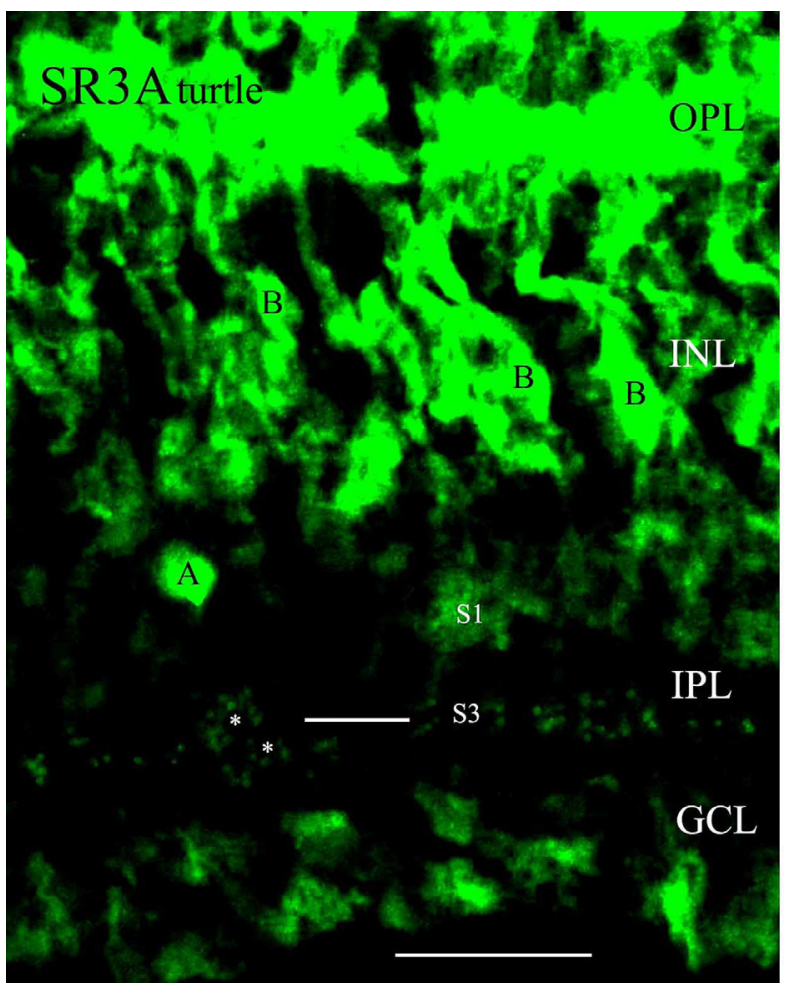

Figure 3. Photomicrograph of a vertical turtle retinal section, immunolabeled for serotonin receptor 5-HT 3A. The retinal layers are as follows: ONL- outer nuclear layer; OPL - outer plexiform layer; INL - inner nuclear layer; IPL - inner plexiform layer; GCL - ganglion cell layer. Note the punctate staining in sublayer $\mathrm{S}_{3}$ of the IPL. Two horseshoe formations, considered to be typical for the membrane receptors on the BCs axons are indicated by small white arrows in the middle. A pear shaped amacrine cell whose single process subdivides in two when enters the IPL $\mathrm{S}_{1}$ sublayer is also seen. B - bipolar cell; A - amacrine cell. Scale bar: $25 \mu \mathrm{m}$. 
The 5-HT 3A receptor immunoreactivity was also very well expressed in the frog and turtle retinas. Retinal sections from the central part of the turtle retina demonstrated very rich staining with the typical distribution of BCs in this region (Fig. 3). Amacrine cells (ACs) bodies were also visualized in both frog and turtle retinal sections. They were usually of two different sizes and were located at different distances from the upper IPL edge (Fig. 3, see also Fig. 9B). Therefore, a conclusion can be made that the 5-HT 3A receptor immunoreactive ACs are not uniform and most probably belong to two different subgroups. Most likely, part of them might be classified as the so called "wide field" AC with their long processes running horizontally in the $\mathrm{S}_{1}$ - and $\mathrm{S}_{3^{-}}$sublayers.

\subsection{GABAergic System}

GABAergic neurons were very well represented in both frog and turtle retinas. The monoclonal GABA antibody caused rich staining in a great number of cell bodies: horizontal (HC) and amacrine cells (AC) mainly (Fig. 4). Both retinal prexiform layers: the outer (OPL) and inner one (IPL), the sites where HCs and ACs make their synaptic contacts, were also very well expressed. A row of HCs bodies located immediately below the OPL, was an obligatory finding in almost all retinal sections The GABAergic ACs' somata were located mainly in the lower part of INL; however, some cell bodies were embedded in the IPL $\mathrm{S}_{1}$ sublayer as well (Fig. 4). The GABAergic ACs were the most numerous cells in all retinal section. Their somata were of different shape and size. Very often they were located in two rows which showed that the GABAergic ACs were not an uniform group (Fig. 4). This observation was confirmed by the double labeling which we carried out with the anti-GABA and anti-calretinin antibodies (not shown here). It has been shown that only a part of the GABAergic ACs had affinity to the calcium binding protein calretinin.

In addition to $\mathrm{HCs}, \mathrm{ACs}$ and both plexiform layers we found GABAergic immunoreactivity in some bipolar cells (BC), single photoreceptors and ganglion cells (GCs) as well (Fig. 4). Presence of GABAergic BCs was evidenced using double labeling with calretinin, well-known to be a marker for $\mathrm{HC}$, $\mathrm{BC}$ and $\mathrm{AC}$ (not shown here). According to our observations, the bigger part of the off- BCs showed calretinin-immunopositivity. On the contrary, on- BCs showed lower calretinin immunoreactivity. Our GABA- immunoreactivity data from the frog and turtle retinas are in good agreement with literature data on similar lower vertebrate animal species [15].

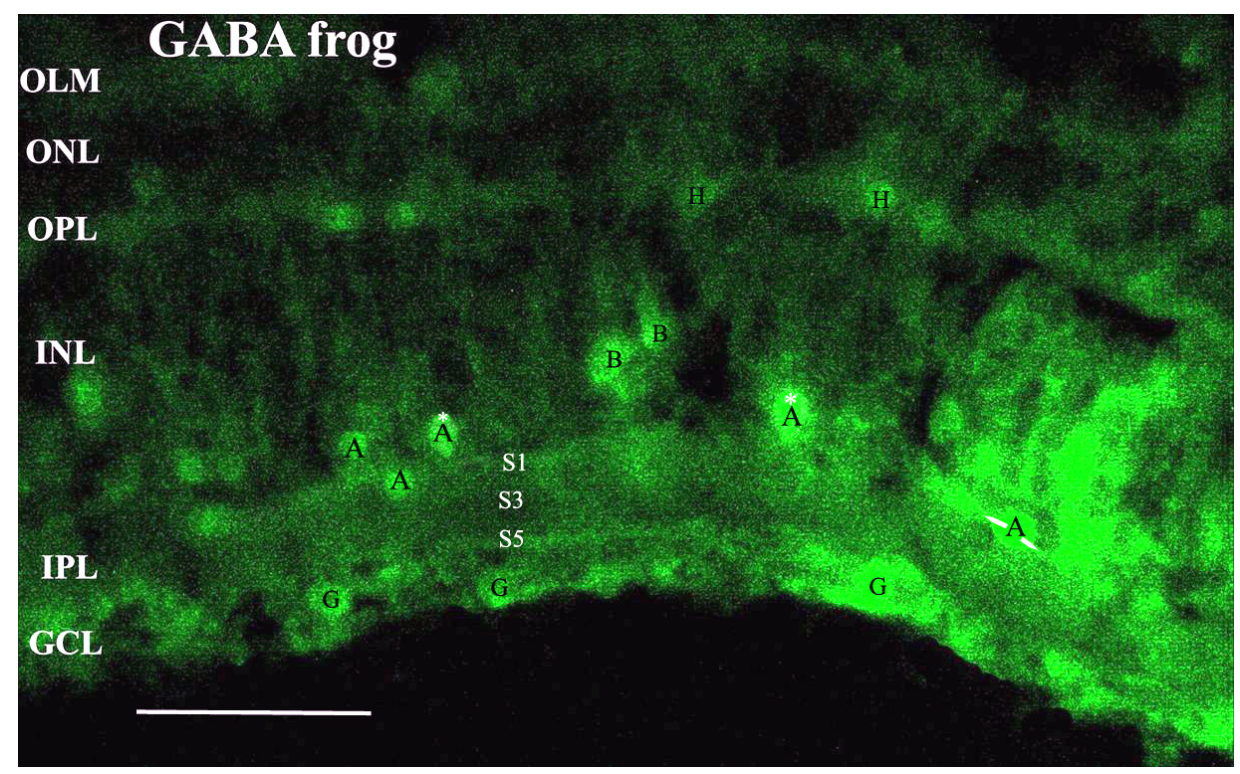

Figure 4. Photomicrograph of a vertical frog retinal section, immunolabeled for GABA. The retinal layers are as follows: OLM - outer limiting membrane; ONL- outer nuclear layer; OPL - outer plexiform layer; INL - inner nuclear layer; IPL - inner plexiform layer; GCL - ganglion cell layer. Other notifications: H - horizontal cell; Bbipolar cell; A - amacrine cell, G - ganglion cell. Representatives of two types of GABAergic ACs are seen: a round shaped one which soma is almost embedded in the $\mathrm{S}_{1}$ sublayer, and two pear shaped ones (indicated by a white asterisk) with their somata located above the IPL. Scale bar: $40 \mu \mathrm{m}$ 
The ionotropic GABA receptors in the frog and turtle retinas were also very well expressed. In the present study we used three antibodies to visualize different subunits of the $\mathrm{GABA}_{\mathrm{A}}$ receptors (two of them were monoclonal) and two antibodies for visualization of the $\mathrm{GABA}_{\mathrm{C}}$ receptor subunits. All the utilized antibodies caused well expressed staining in both synaptic layers (Fig. 5, Fig. 6). In the IPL it was represented by numerous puncta, better seen at larger magnification of the microscope. Sometimes the puncta were organized in well defined parallel rows. It might be assumed that several different groups or subgroups of retinal neurons use the respective GABA receptor subunit to influence the activity of their postsynaptic partners. Our present observations concerning the synaptic distribution of $\mathrm{GABA}_{\mathrm{A}}$ and $\mathrm{GABA}_{\mathrm{C}}$ receptors in the frog and turtle retinas are in good agreements with our initial studies on the ionotropic GABA receptors [12], where we used antibodies directed against other subunits of the same receptors. Still, the data from the two studies are not contradictory. The GABA receptor immunoreactivity was more diffuse and usually comprised the whole width of IPL, while the $\mathrm{GABA}_{\mathrm{C}}$ receptor immunoreactivity was concentrated predominantly around the IPL central band. This finding was better shown in our previous study [12; Fig. 2], where the anti-GABA $\mathrm{C}_{\mathrm{C}}$ antibody used was sensitive to all three isoforms $\left(\rho_{1}, \rho_{2}\right.$ and $\left.\rho_{3}\right)$ of the receptor's subunit.

In addition to the synaptic staining in both plexiform layers, the anti-GABA $A_{A}$ and anti-GABA receptor antibodies caused visualization of single cell bodies as well. Similarly to all proteins, the postsynaptic membrane receptors are synthesized in the soma and are transported to the respective postsynaptic structures. Therefore, GABA receptor antibodies allow visualization of these postsynaptic structures, which in fact are partners of the GABAergic neurons. According to our data most frequent partners to the GABAergic HCs and ACs are certain non-GABAergic horizontal cells, a vast majority of bipolar cells and a large group of amacrine cells. These interactions are mediated by $\mathrm{GABA}_{\mathrm{A}}$ and $\mathrm{GABA}_{\mathrm{C}}$ receptors, which are two different subpopulations of the ionotropic GABA receptors. These two types of receptors are located on different postsynaptic structures. Based on our experiments, we may conclude that while the majority of $\mathrm{GABA}_{\mathrm{C}}$ receptors are located on the $\mathrm{BCs}$ axons (Fig. 6), one significant part of $\mathrm{GABA}_{\mathrm{A}}$ receptors mediates interactions between different types of amacrine cells (Fig. $5)$.

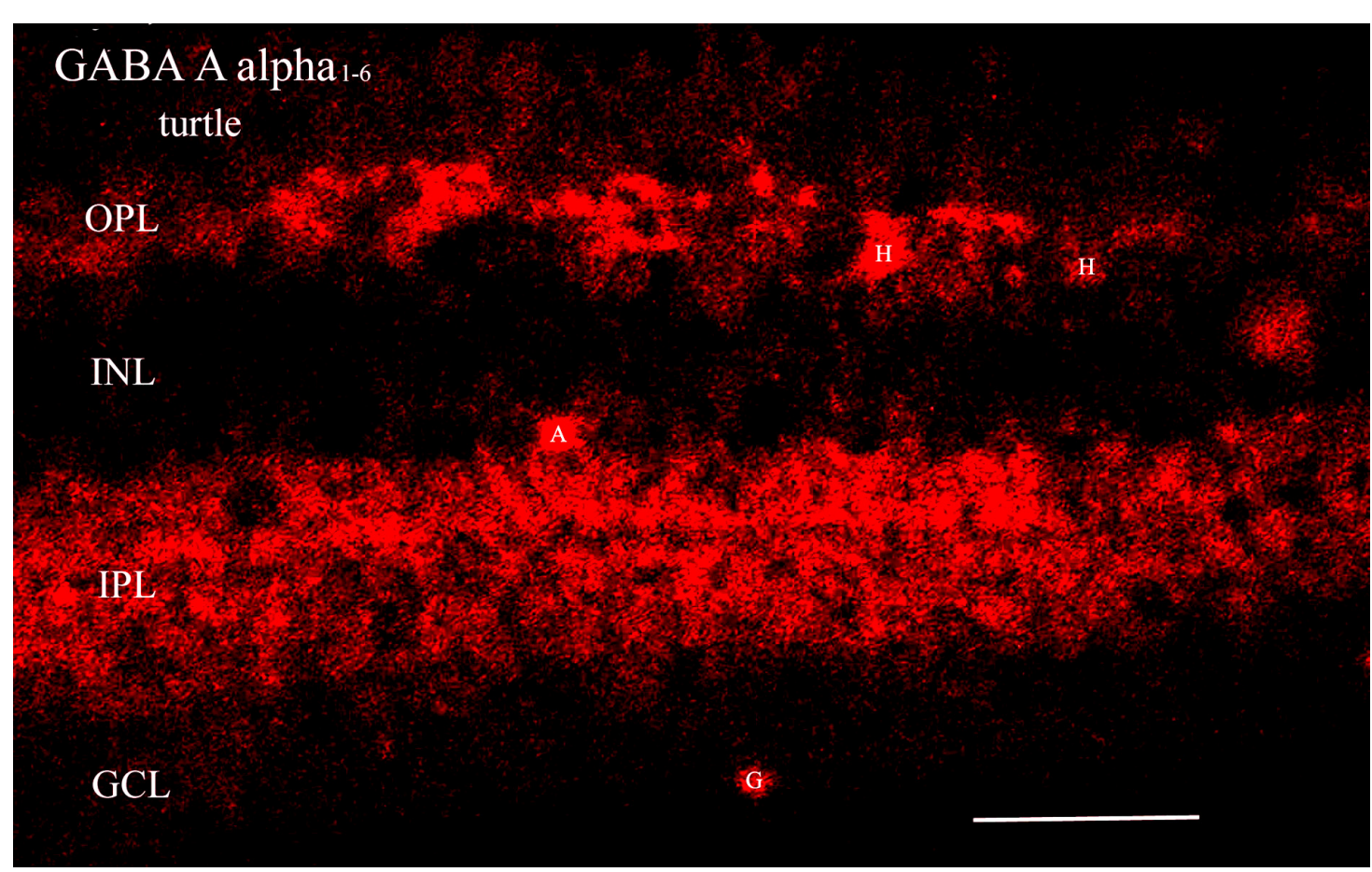

Figure 5. Photomicrograph of a vertical turtle retinal section, immunolabeled for alpha 1-6 subunit of GABA A receptor. The retinal layers are as follows: ONL- outer nuclear layer; OPL - outer plexiform layer; INL - inner nuclear layer; IPL - inner plexiform layer; GCL - ganglion cell layer. Note the numerous spots in the IPL, a typical sign for the ionotropic receptors' staining. The spots are organized in several sublayers, the distal sublayers being brighter than the proximal ones. Other notifications: H - horizontal cell; A - amacrine cell, G - ganglion cell. Scale bar: $30 \mu \mathrm{m}$. 


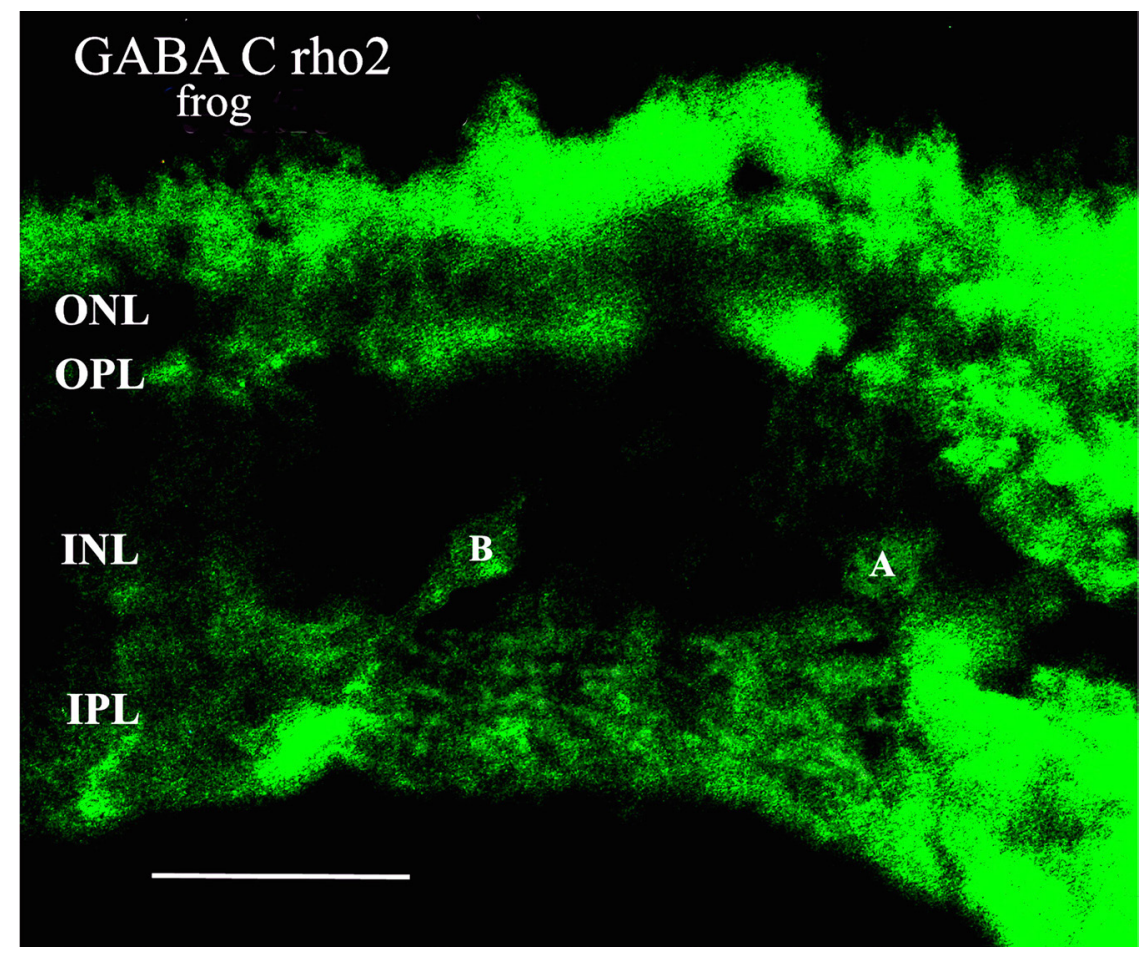

Figure 6. Photomicrograph of a vertical frog retinal section, immunolabeled for rho2 subunit of GABA C receptor. The retinal layers are as follows: ONL- outer nuclear layer; OPL - outer plexiform layer; INL - inner nuclear layer; IPL - inner plexiform layer; GCL - ganglion cell layer. Scale bar: 35 m.

\subsection{Possible Interactions between the Two Neurotransmitter Systems: Double Labeling Experiments}

In order to reveal the putative interactions between the serotoninergic and the GABAergic neurotransmitter systems, we planned to carry out two series of double labeling experiments. Each series included staining with two antibodies - the first one directed against certain of the neurotransmitters, and the second one - directed against the membrane receptors of the opposite neurotransmitter group. Thus we expected to answer the question if the serotoninergic neurons in the frog and turtle retina expressed GABA receptors on their cell membrane, and vice versa: if the GABA-ergic neurons expressed serotoninergic membrane receptors. If we succeeded to demonstrate co-localization of a neurotransmitter and some of the receptors of the opposite neurotransmitter system on one and the same neuron, it would mean that the needed microstructural characteristics for functional interactions between the two neurotransmitters systems were present.

\section{Double labeling serotonin/ionotropic $G A B A$ receptors}

Firstly, we decided to check out if the serotoninergic neurons possessed ionotropic GABA receptors on their cell membranes. Such co-localization would enable GABA to influence the activity of the serotoninergic neurons. The two neurotransmitter systems are very well expressed both in the proximal and in the distal retina, in the latter serotonin being precursor of melatonin synthesis in the photoreceptors. However, we decided to focus our attention mainly on the proximal retina, where a great number of GABAergic and serotoninergic ACs, BCs and GCs form their synaptic contacts.

We made two double labelings: serotonin/GABA $\mathrm{G}_{\mathrm{A} \text { (alpha1-6) }}$ receptors (Fig. 7) and serotonin/GABA $\mathrm{GA}_{\mathrm{C} \text { (ro2) }}$ receptor (Fig. 8). We showed a principal difference between the two groups of experiments. While a relatively large number of co-localizations between the serotonin and the $\mathrm{GABA}_{\mathrm{A}(\mathrm{alpha1}-6)}$ receptor antibodies existed, no co-localizations between the serotonin and $\mathrm{GABA}_{\mathrm{C}(\mathrm{rho} 2)}$ receptor antibodies were found. The co-localizations were demonstrated as numerous yellow colored small spots spread through the IPL (Fig. 7). If we try to "organize" them in relation to the subdivision of IPL in several sub-layers, they might be localized predominantly in $S_{1}$ and $S_{3}$, and are rarer in $S_{5}$. The $S_{1}$ and $S_{3}$ IPL sub-layers are 
the sites where a great amount of ACs forms their synaptic contacts. As the membrane receptors are mainly located on the postsynaptic neurons, a conclusion can be made, based on the results of these double labeling, that a great number of GABAergic ACs can influence the activity of serotoninergic neurons using predominantly $\mathrm{GABA}_{\mathrm{A}}$, but not $\mathrm{GABA}_{\mathrm{C}}$ receptors. The numerous co-localizations seen in Fig. 7 may be interpreted as sites of synaptic contacts between the GABAergic ACs and the serotoninergic ACs. The existence of numerous similar inter-neuronal interactions between different classes of amacrine cells, defined as "serial synapses" is well-known. Undoubtedly, predominantly the $\mathrm{GABA}_{\mathrm{A}}$, but not the $\mathrm{GABA}_{\mathrm{C}}$ receptors, mediate the inhibition, which the GABAergic ACs can exert on the serotoninergic ACs.

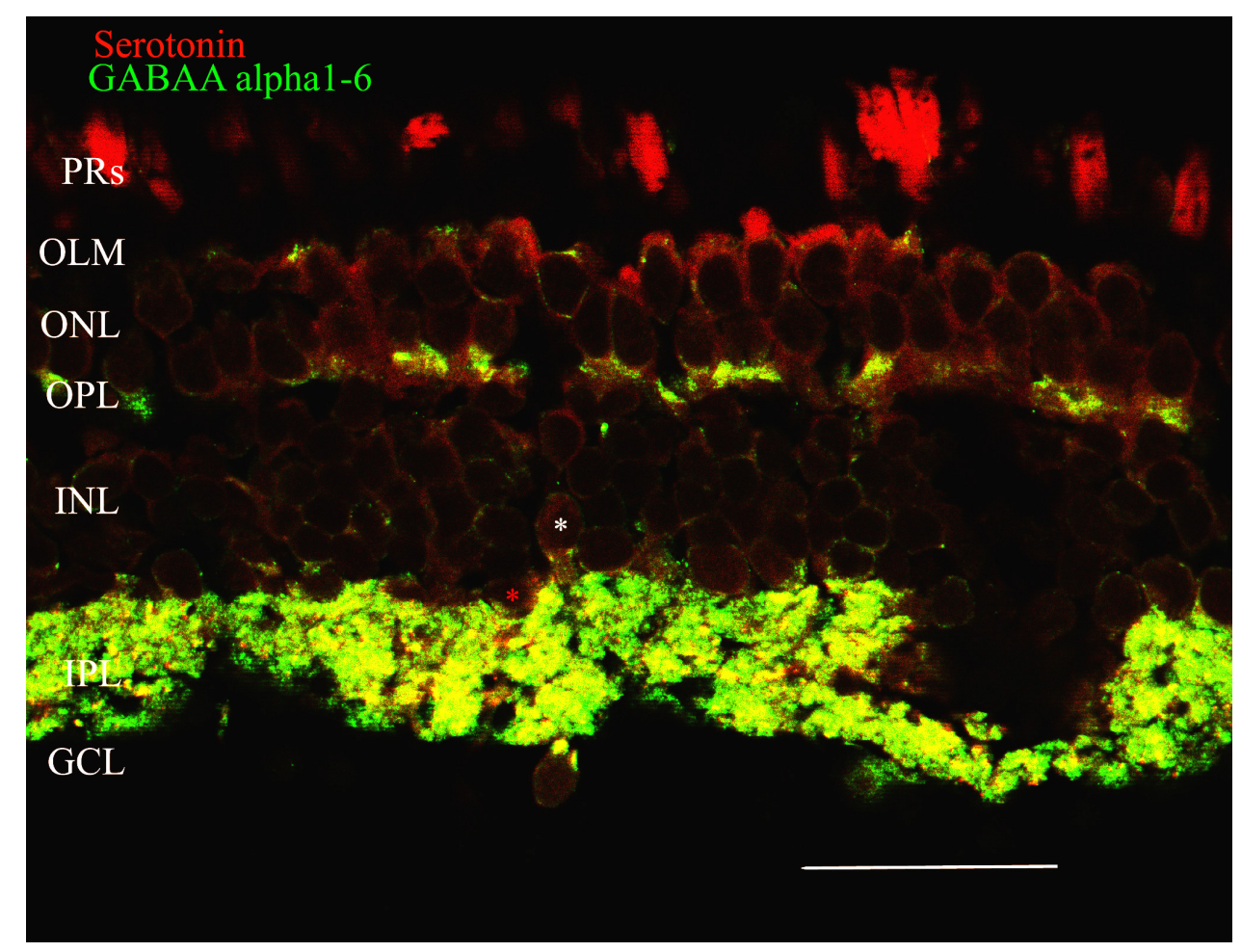

Figure 7. Confocal microscopic view of a vertical frog retinal section, double labeled for serotonin (red) and $\mathrm{GABA}_{\mathrm{A}(\text { alpha1-6) }}$ receptor (green). The places of co-localization between the two antibodies are colored yellow. Note the two types of amacrine cells: a round shaped with its body almost embedded in the $\mathrm{S}_{1}$ (red asterisk), and pear shaped with its relatively large cell body above the IPL (white asterisk). The retinal layers are as follows: PRs inner segments of photoreceptors; OLM - outer limiting membrane; ONL- outer nuclear layer; OPL - outer plexiform layer; INL - inner nuclear layer; IPL - inner plexiform layer; GCL - ganglion cell layer. Scale bar: 35pm.

\section{Double labeling $G A B A /$ serotonin receptors}

In order to elucidate the putative presence of serotoninergic membrane receptors in the GABAergic neurons, we carried out double labeling with two monoclonal antibodies: anti-GABA and anti-5-HT2A receptor (Fig. 9A). Co-localizations were observed in several levels of both distal and proximal retina. Yet, we focused again on the IPL level only. Immediately above the IPL, we noticed several small groups of amacrine cells' bodies. Frequently, a yellow colored AC type was noticed; it had a typical appearance with the two processes very often positioned at $180^{\circ}$ angle to each other. In some cases these two processes originated from one single process leaving the cell's soma. After the subdivision, they were followed to run in two opposite directions in the most superficial IPL sublayer, $\mathrm{S}_{1}$. Collaterals of this process were sometimes followed in sublayer $\mathrm{S}_{3}$. These cells were proved to be GABAergic ones. Some authors described them as "widefield", because of the wide area in which these neurons send their processes to form synaptic contacts. Our double labeling experiments unequivocally showed that they expressed serotonin receptors on their cell membranes, which made them good candidates to mediate influences from the serotoninergic system. 
In addition to the 5-HT 2A, this subtype of amacrine cells may also possess 5-HT3A receptors on its surface (Fig. 9B). In another double labeling study, where we applied two antibodies - anti- 5-HT2A receptor and anti- 5-HT3A receptor - on one and the same retinal section, we found co-localizations between them. Therefore, both types of serotonin receptors expressed in the so called "widefield" GABAergic AC might be able to mediate the serotonin influences on the GABAergic system in the retina (Fig. 9B).

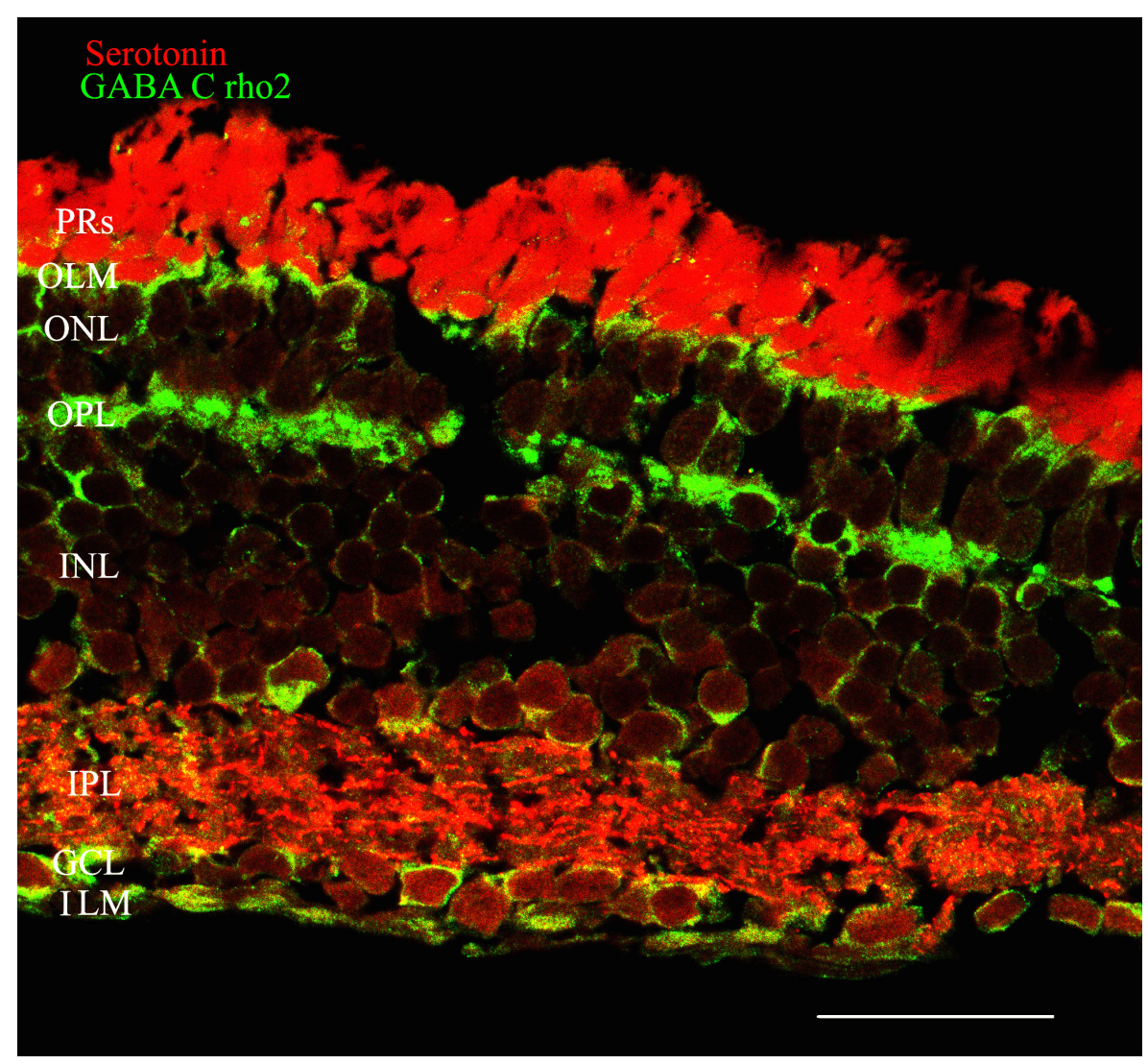

Figure 8. Confocal microscopic view of a vertical frog retinal section, double labeled for serotonin (red) and $\mathrm{GABA}_{\mathrm{C}(\text { rho2) }}$ receptor (green). The retinal layers are as follows: PRs - photoreceptors inner segments; OLM - outer limiting membrane; ONL- outer nuclear layer; OPL - outer plexiform layer; INL - inner nuclear layer; IPL - inner plexiform layer; GCL - ganglion cell layer; ILM - inner limiting membrane. Scale bar: 35um.

\section{Discussion}

Based on our experimental data, we might suggest several options for interaction between the serotoninergic and GABAergic systems in the frog and turtle retinas. Both neurotransmitter systems are very well expressed in the retina. GABA is the main inhibitory neurotransmitter in the retina, while serotonin - known as both neurotransmitter and neuromodulator, may produce (depending on the type of the postsynaptic membrane receptors) both excitatory and inhibitory influences. Serotonin is also very richly expressed in the retina. In addition to its several retinal sources [7], retinopetal serotoninergic nerve fibers are also present $[16,17]$. These neurons enter the retina through the optic disc, branch extensively and release serotonin from their numerous varicosities, thus influencing the numerous retinal receptors.

Can the GABAergic and the serotoninergic system interact? Using the indirect immunocytochemical method, we proved that such interactions were possible. Our data showed that representatives of the serotoninergic neurons expressed ionotropic GABA receptors on their cell membranes (predominantly $\mathrm{GABA}_{\mathrm{A}}$ ) and vice versa: representatives of the GABAergic system possessed the serotonin receptors 5HT2A and 5-HT3A. 
It is known that the ionotropic GABA receptors are chloride ion channels, subdivided into two different subtypes: $\mathrm{GABA}_{\mathrm{A}}$ and $\mathrm{GABA}_{\mathrm{C}}$ receptors. As already mentioned, while the $\mathrm{GABA}_{\mathrm{A}}$ are most frequently composed of two alpha, one beta, one gamma and one delta subunits, $\mathrm{GABA}_{\mathrm{C}}$ receptors are composed of rho1, rho2 and rho3 subunits. In our double labeling experiments we used an antibody against all splice variants of the alpha subunit. This subunit is indispensable for the normal function of the channel and is the most numerous one as compared to other subunits. Our results unequivocally showed that the serotoninergic neurons expressed alpha subunits of $\mathrm{GABA}_{\mathrm{A}}$ receptor on their cell membranes. We also showed that the number of the retinal $\mathrm{GABA}_{\mathrm{A}}$ receptors on the serotoninergic neurons significantly exceeded the number of $\mathrm{GABA}_{\mathrm{C}}$ receptors (compare Fig. 7 and Fig. 8). Our hypothesis is as follows: It has been shown that the $\mathrm{GABA}_{\mathrm{A}}$ receptors are mainly located on the $\mathrm{ACs}$, while the $\mathrm{GABA}_{\mathrm{C}}$ receptors are supposed to be located predominantly on the BCs $[12,18,19]$. Since the serotoninergic BCs are represented mostly around the visual streak [7], they are not as numerous as the serotoninergic ACs, which are spread all over the retina. Therefore, the number of co-localizations of serotoninergic neurons with $\mathrm{GABA}_{\mathrm{C}}$ receptors must be lower as compared to the number of their colocalizations with the $\mathrm{GABA}_{\mathrm{A}}$ receptor. We might suppose that this ratio will not be one and the same for the central and peripheral parts of the retina. Summarizing our results, we may suggest the existence of GABAergic influences upon the serotoninergic system. These interactions are most numerous at the level of IPL, where the GABAergic ACs may inhibit (predominantly through the GABA $_{\mathrm{A}}$ receptors) the serotoninergic ACs.
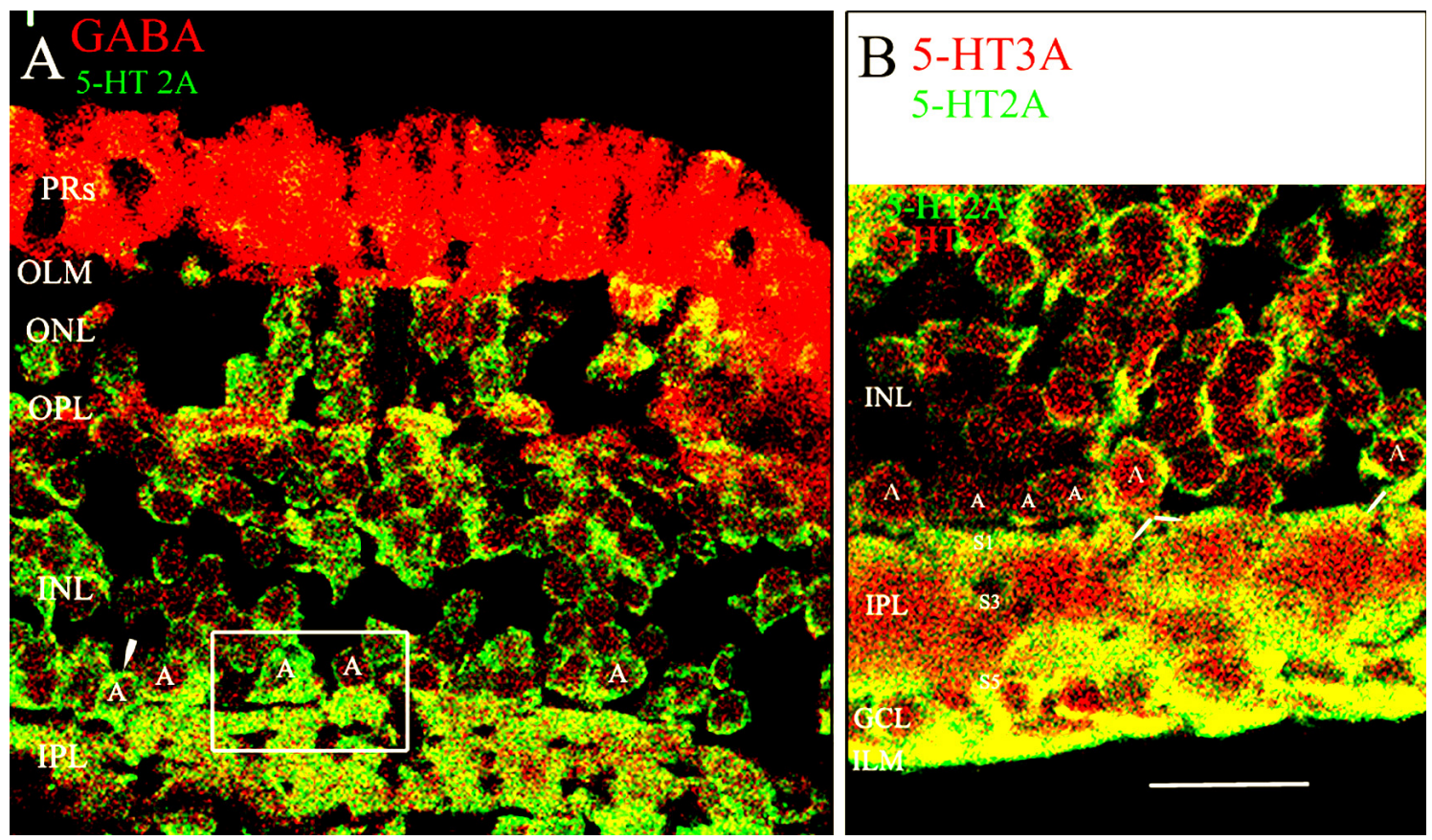

Figure 9. Confocal microscopic view of two vertical frog retinal sections, double labeled for: A - GABA (red) and 5-HT2A (green), and B - 5-HT2A (green) and 5-HT3A (red). The retinal layers are as follows: PRs -photoreceptors inner segments; OLM - outer limiting membrane; ONL- outer nuclear layer; OPL - outer plexiform layer; INL inner nuclear layer; IPL - inner plexiform layer; GCL - ganglion cell layer; ILM - inner limiting membrane. A: Numerous GABAergic amacrine cells of different size and shape can be seen immediately above the border between INL and IPL. Two of them are enclosed by a white rectangle. Note the yellow colored small puncta inside the rectangle. The pear shaped soma of another AC, supposed to belong to the so called "widefield" amacrine cells is indicated by a white arrowhead. Note the fine yellow puncta on its membrane. B. Both 5-HT 2A and 5-HT3A serotonin receptors' antibodies co-localize on the cell bodies and the processes of several large amacrine cells with typical "pear" shape (indicated by the capital letter A). Their two main processes run in parallel in the IPL sublayer S1 (see the white colored arrowheads). However, branches of their processes go downwards and spread in sublayer S3 as well. In addition to the large pear-shaped amacrine cells, small size amacrine cells (indicated by smaller size letter A) are also evident. No co-localization between the 5-HT2A and 5HT-3A antibodies is observed. Scale bar: $35 \mu \mathrm{m}$ in $\mathrm{A}$ and $20 \mu \mathrm{m}$ in B. 
We focused only on the 5-HT 2A and 5-HT3A receptors from the numerous 5-HT receptor types. While 5-HT 2A is a metabotropic (G-protein coupled) receptor, the 5-HT3A is the only ionotropic receptor amongst the serotonin receptors. A common feature of both receptors is their ability to cause depolarization of the postsynaptic structure. Since even the slightest depolarization at the postsynaptic level can facilitate the release of the corresponding neurotransmitter, the presence of 5-HT 2A and 5-HT $3 \mathrm{~A}$ receptors on the membrane of a GABAergic neuron may be interpreted as a possibility this cell to be stimulated to release GABA under the effect of serotonin. Our results confirm the presence of serotoninergic receptors 5-HT 2A and 5-HT 3A on the surface of the GABAergic neurons - mainly on amacrine cells (Fig. 9), that can explain the possibility GABA activity to be modulated by serotonin. Our results showed that both serotonin receptors: 5-HT2A and 5-HT3A co-localize with GABA in some of the GABAergic amacrine cells. In addition, it seems that one and the same AC can express both types of receptors (Fig. 9B). That's why we believe that the serotonin receptors 5-HT 2A and 5-HT 3A are good candidates to mediate the effect of serotonin on the GABAergic system.

Recently, we studied the effects on the frog electroretinogramm of TACA, an agonist of the ionotropic GABA receptors with some prevalence on the $\mathrm{GABA}_{\mathrm{C}}$ receptors [20, 21]. TACA was applied alone or at the background of preliminary application of serotonin. When applied alone, TACA caused well expressed decrease of the ERG b- and d- waves amplitudes. Serotonin alone caused slight stimulation of both b- and d- wave amplitudes. In case of TACA application at the background of manifested serotonin stimulation, it caused significantly smaller suppression of the b- and d-wave amplitudes (Fig. $10 \mathrm{~A})$. These results showed that at the background of serotonin application the inhibitory effect of $\mathrm{GABA}_{\mathrm{A}}$ and $\mathrm{GABA}_{\mathrm{C}}$ receptors on the frog ERG decreases [21]. How these electrophysiological results might be explained? Our present immunocytochemical data could help to answer this question. It is known that the ERG reflects predominantly the activity of the retinal on- and off- bipolar cells (BCs), the main "generators" of b- and d- wave correspondingly. At the level of the IPL, however, this BCs activity undergoes a sustained inhibition, caused by a certain class of GABAergic ACs, affecting predominantly the $\mathrm{GABA}_{\mathrm{C}}$ receptors on the $\mathrm{BCs}$ axons $[12,22]$. What might be the intimate mechanism of reduction of this ACs' nhibition on the BCs activity after serotonin application? It is known that different types of amacrine cells are interconnected in the IPL in a chain. These are the so called "serial synapses" described in many types of retinas, including the frog and turtle ones [23, 24]. We propose here a simple chart based on the synaptic interconnection between one $\mathrm{BC}$, regarded as an ERG generating unit, and two GABAergic ACs: $\mathrm{AC} 1$ and $\mathrm{AC} 2$ (Fig. 10B). Let us assume that the $\mathrm{AC} 1$ is a GABAergic amacrine cell which makes direct synaptic contact with the ERG-generating BC and suppresses its activity. AC1 is influenced alone by another GABAergic amacrine cell, indicated as AC2 (Fig. 10B). Our hypothesis is that the second GABAergic AC (AC2) might express serotonin receptors. This suggestion was confirmed by our double labeling experiments, the confocal microscopic photomicrographs of which are represented in Fig. 9A and Fig. 9B. We proved that the second type GABAergic ACs, AC2, expressed the serotonin receptors 5HT-2A and 5-HT 3A. These amacrine cells were usually "pear" shaped. They had relatively large soma with a single thick process, which further subdivided in two processes positioned very often at $180^{\circ}$ to each other (Fig. 9, Fig. 10B). These cells are usually called "widefield" ACs, as already mentioned. Their processes undergo rich arborization in the S1 and S3 sublayers of IPL mainly. As a result of the serotonin binding to its receptor, the AC2 depolarizes and releases GABA, which on its turn inhibits (most probably through a $\mathrm{GABA}_{\mathrm{A}}$ receptor) the activity of the first GABAergic AC (AC1) (Fig. 10B). Due to this desinhibition, the BCs activity could be sensitized and facilitated. It was really observed in our ERG experiments in cases when serotonin and TACA were applied together.

Similar mechanism has been recently proposed to explain the dopamine sensitization of rod bipolar cells in the mouse retina [25]. As both monoamines have a lot of similarities in their distribution and functions in the retina, the possibility for utilization of similar mechanism is quite possible. Moreover, the presence of one and the same type of interactions between GABA - from one side and dopamine or serotonin - from other, in both lower vertebrate and Mammalian retinas may be interpreted as a basic feature of the nervous system information processing. 

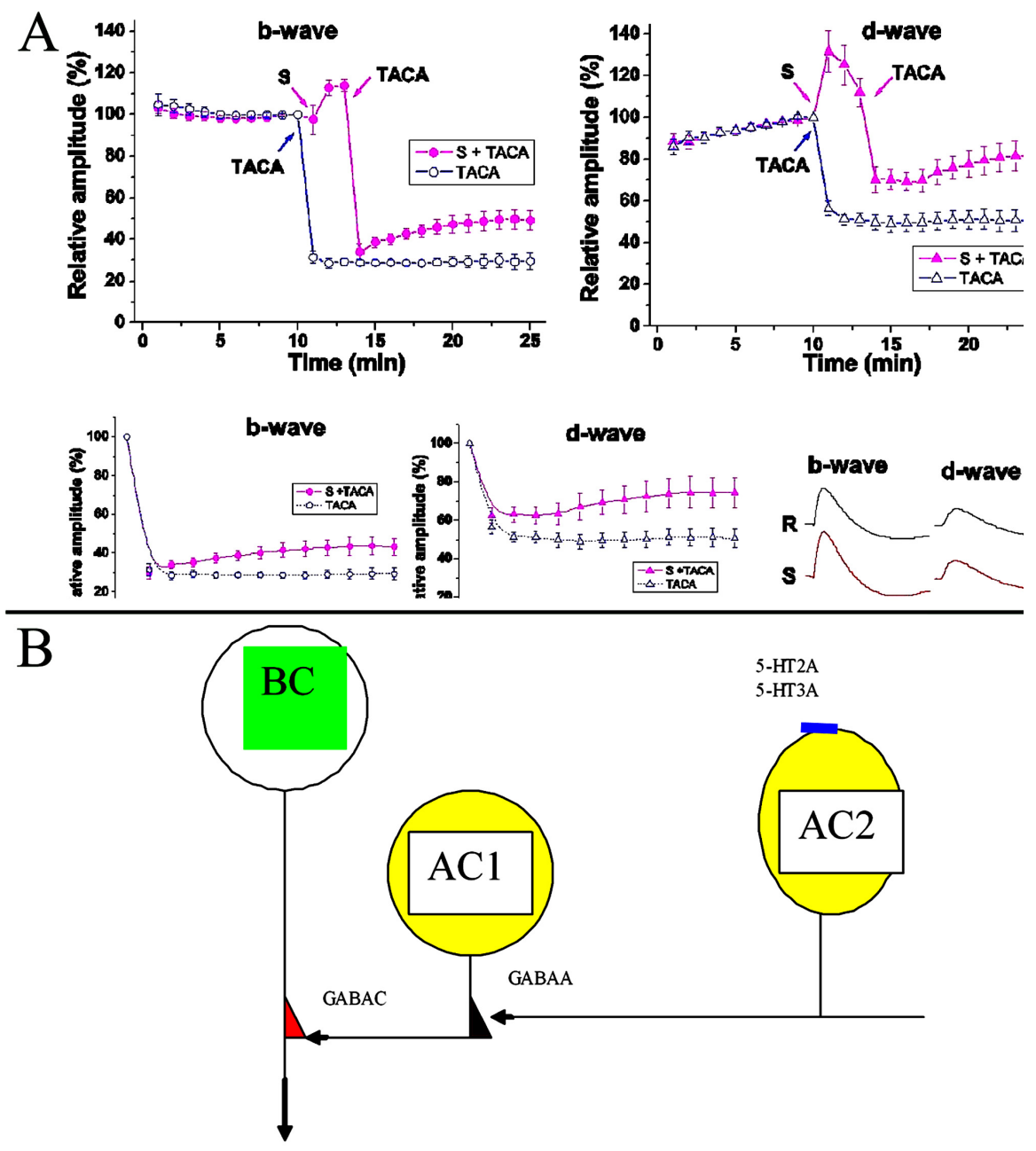

Figure 10. A. Effect of combined action of serotonin plus TACA (an agonist of ionotropic GABA receptors) on the frog ERG b- and d-waves. Upper row: Time courses of the effects of serotonin (100 $\mu \mathrm{M})(\mathrm{S})+\mathrm{TACA}(5 \mathrm{mM})(\mathrm{S}+$ TACA) on the amplitude of the ERG b- and d-waves (filled symbols). Compare these results with the results in the group where only TACA was applied (open symbols). The amplitude of the ERG waves were normalized to the values obtained on the 10th minute from the beginning of the experiments. Mean values \pm SEM are represented. Low row: Relative amplitude changes of b- and d- waves in S+TACA group and TACA group. The amplitudes of the b- and d-waves are normalized to the values obtained just before the TACA application ( 0 min). End of the row: original ERG curves at different conditions: R - Ringer; S - serotonin. B. Scheme, illustrating the putative interactions between two GABAergic amacrine cells (AC1 and AC2) and one bipolar cell (BC). The "wide field" amacrine cells AC2 is supposed to possess the serotonin receptors 5-HT2A or 5-HT 3A (denoted in blue). AC2 make synaptic contacts with another GABAergic amacrine cell, AC1, by means of GABAA receptors (denoted in black). AC1 make synaptic contact with the bipolar cells (BC) by means of GABA C receptors (denoted in red). The activation of $\mathrm{AC} 2$ by serotonin may suppress $\mathrm{AC} 1$ activity which would cause desinhibition of the $\mathrm{BC}$ activity

\section{Conclusion}

Our immunocytochemical results showed that neurons of the GABAergic system express serotoninergic receptors on their cell membranes and vice versa: the serotoninergic neurons express ionotropic GABA receptors. This structural precondition gives the ground for functional interactions between the two neurotransmitter systems. We succeeded to prove the idea that serotonin could decrease the activity of GABA receptors, predominantly $\mathrm{GABA}_{\mathrm{C}}$ ones, which regulate the output of the main retinal neurons, the bipolar cells. In such a way, our results confirm the idea that serotonin can negatively modulate the 
GABA $\rho$ receptors expression in Xenopus laevis oocytes [13]. Our results are in agreement with the data of some other authors who also showed reciprocal relations between the two systems in different brain regions $[26,27]$.

To the best of our knowledge, our study is the first focused on the serotonin and GABA relationships at the level of lower vertebrate retina, recognized as a good biological model of brain functions. Special attention was paid on elucidating the mechanism, by which the retinal serotonin may decrease the inhibitory effects of GABA mediated by its ionotropic receptors. We focused our attention at the IPL level, where the bipolar cells - the "main block" generating retinal activity forms its output activity. It does not exclude similar interactions between the two neurotransmitters systems to exist at another retinal level as well. As the retina is a natural biological model of the CNS, it may be supposed that the similar relationships between the serotoninergic and GABAergic neurotransmitters systems exist at certain brain levels as well, which may explain the possible mechanism of action of some antidepressant drugs.

Acknowledgments. This work was partially supported by the Medical Science Council of the Medical University Sofia, Bulgaria (Grant \# 12/ 2016; main investigator L. Vitanova). A part of the results included in this paper was reported at the $38^{\text {th }}$ World Congress of IUPS, held in Rio de Janeiro, Brazil from 1 to 5 august 2017.

The author declares that during the experiments all the institutional, national and EU guidelines for care and use of laboratory animals were strictly followed.

The author wishes to thank to assoc. prof. E. Popova and assoc. prof. P. Kupenova from the Medical University Sofia for carrying out the electrophysiological experiments and conceding the results for common discussion, as well as to assoc. prof. N. Belova from the same University for her critical reading of the English version of the manuscript.

Special thanks also to assoc. prof. Milena Mourjeva from the Institute of Immunology of Reproduction from the Bulgarian Academy of Sciences for her help while the confocal retinal images were performed

\section{References}

1. Ehinger B (1983). Connexions between retinal neurons with identified neurotransmitters. Vision Res; 23(11):1281-91.

2. Vígh J, Bánvölgyi T, Wilhelm M. (2000). Amacrine cells of the anuran retina: morphology, chemical neuroanatomy, and physiology. Microsc Res Tech 2000; 50(5):373-83.

3. Zhu B, Gábriel R, Straznicky C(1992). Serotonin synthesis and accummulation by neurons of the anuran retina. Vis Neurosci 1992; 9(3-4):377-88.

4. Ghai K, Zelinka C, Fischer AJ (2009). Serotonin released from amacrine neurons is scavenged and degraded in bipolar neurons in the retina. Neurochem. 111(1):1-14. doi: 10.1111/j.1471-4159.2009.06270.x.

5. Schütte M, Weiler R. Morphometric analysis of serotoninergic bipolar cells in the retina and its implications for retinal image processing. J Comp Neurol 1987; 260(4):619-26.

6. Schütte M. Serotonergic and serotonin-synthesizing cells of the Xenopus retina. Int J Neurosci 1994; 8(1-2), 67-73.

7. Vitanova L, Kupenova P, Zhekova D (2017a). Tryptophan hydroxylase and serotonin receptors 5-HT1A, 5-HT2A, 5-HT3A, 5-HT4, 5-HT 5A, 5-HT 6 and 5-HT 7 in frog and turtle retina: an immunofluorescence study. J Adv Mol Biol., 1(1), 33-72.

8. Cornide-Petronio ME, Anadón R, Rodicio MC, Barreiro-Iglesias A (2013). The sea lamprey tryptophan hydroxylase: new insight into the evolution of the serotonergic system of vertebrates. Brain Struct Funct., 218(2): 587-93.

9. Cornide-Petronio ME, Anadón R, Barreiro-Iglesias A, Rodicio MC (2015). Tryptophan hydroxylase and serotonin receptor 1A expression in the retina of the sea lamprey. Exp Eye Res, 135:81-7.

10. Nichols DE, Nichols CD. (2008) Serotonin receptors. Chem. Rev, 108(5), 1614 - 164. doi: 10.1021/cr078224o. Epub 2008 May 14. Review.

11. Olsen RW, Sieghart W. (2009). GABA A receptors subtypes provide diversity of function and pharmacology, Neuropharmacol 56, 141-8. 
12. Vitanova L, Kupenova P, Haverkamp S, Popova E, Mitova L, Wässle H (2001). Immunocytochemical and electrophysiological characterization of GABA receptors in the frog and turtle retina. Vision Res. 41(6): 691-704.

13. Ochoa-de la Paz LD, Estrada-Mondragón A, Limón A, Miledi R, Martínez-Torres A (2012). Dopamine and serotonin modulate human GABAp1 receptors expressed in Xenopus laevis oocytes. ACS Chem Neurosci, 3(2):96-104.

14. Hurd LB 2nd, Eldred WD. (1993). Synaptic microcircuitry of bipolar and amacrine cells with serotonin-like immunoreactivity in the retina of the turtle, Pseudemys scripta elegans. Vis Neurosci;10(3):455-71.

15. Gábriel R, Zhu BS, Straznicky C (1993). Synaptic contacts of serotonin-like immunoreactive and 5,7dihydroxytryptamine-accumulating neurons in the anuran retina. Neuroscience.54(4):1103-14.

16. Gastinger MJ, Bordt AS, Bernal MP, Marshak DW (2005). Serotonergic retinopetal axons in the monkey retina. Curr Eye Res, 30(12):1089-95.

17. Lima L, Urbina M (1998). Serotonergic projections to the retina of rat and goldfish; Neurochem, 32(2):133-4.

18. Lukasiewicz PD, Eggers ED, Sagdullaev BT, McCall MA. (2004). GABAC receptor-mediated inhibition in the retina; 44(28):3289-96. https://www.ncbi.nlm.gov/pubmed/155359996.

19. Vitanova L, Kupenova P, Popova E. (2017b). Immunocytochemical study on the possible interactions between serotonin and GABA C (GABA A rho) receptors in frog retina. IUPS $38^{\text {th }}$ World Congress, Abst. No576. (https://icongresso.itarget.com.br/useradm/anais/?clt=ips.2\&lng=I).

20. Popova E, Kupenova P, Vitanova L. (2017). Interaction between the serotoninergic and GABAergic systems in the frog retina as revealed by the electroretinogram. IUPS $38^{\text {th }}$ World Congress, Abst..No 568 (https://icongresso.itarget.com.br/useradm/anais/?clt=ips.2\&lng=I).

21. Popova E., Kupenova P. (2017) Interaction between the serotoninergic and GABAergic system in frog retina, as reveales by electroretinogram. Acta Neurobiol.Exp, 77: $351-36$.

22. Fletcher EL, Waessle K (1999). Indoleamine-accumulating amacrine cells are presynaptic to rod bipolar cells through GABA(C) receptors. J Comp Neurol. 1999; 413(1):155-67.

23. Eggers ED, Lukasiewicz PD (2010). Interneuron circuits tune inhibition in retinal bipolar cells. J Neurophysiol.;103(1):25-37.

24. Eggers ED, Lukasiewicz PD (2011). Multiple pathways of inhibition shape bipolar cell responses in the retina. Vis Neurosci.; 28(1):95-108.

25. Travis AM, Heflin SJ, Hirano AA, Brecha NC and Arshavsky VY (2018). Dopamine-dependent sensitization of rod bipolar cells by GABA is conveyed through wide-field amacrine cells. J. Neurosci, 38(3): 723-732.

26. Bagdy E, Kiraly I, Harsing LG Jr. (2000). Reciprocal innervation between serotonergic and GABAergic neurons in raphe nuclei of the rat. Neurochem Res; 25(11):1465-73.

27. Feng J, Cai X, Zhao J, Yan Z. (2001). Serotonin receptors modulate GABA(A) receptor channels through activation of anchored protein kinase $\mathrm{C}$ in prefrontal cortical neurons, 21(17):6502-11. 